\title{
NOTES ON THE BEHAVIOR OF TROPIDURUS MELANOPLEURUS BOULENGER (REPTILIA, SAURIA, IGUANIDAE)
}

Virginia Abdala and Martha Patricia Ramirez Pinilla ${ }^{1}$

\section{SUMMARY}

Field observations on a population of Tropidurus melanopleurus confirm conspecificity by detection of courtship behavior. Peculiarities in female and juvenile behavior were observed in this poor known species.

Overall observations were conducted on a population of Tropidurus melanopleurus from Aguas Blancas (Salta, Argentina) near the frontier with Bolivia, on the south bank of the Bermejo river.

The observed population inhabits areas that are lacking in vegetation almost completely. The lizards are either found on vertical walls made of tertiary sedimentary rocks, which were exposed by the construction of a road, or on the sandy shore of the river, which probably corresponds to its original biotope.

The population of this region has been described as two species, $T$. pictus and $T$. praeornatus, which can be differentiated by their morphology and coloration (Muller, 1924). Peters and Donoso-Barros (1970). placed both in the synonymy of T. melanopleuris, Boulenger. Laurent (1980) describes the sexual dichromatism for specimens of this species collected in the National Park of Baritu (Salta, Argentina), area to which the observed population belongs. The first indication of conspecificity of $T$. pictus and $T$. praeornatus as suggested by Laurent, came from observation of their courtship behavior. This was confirmed by our observations. These were conducted during a collection trip in January 1989, between 1050 and 1250 hours. We were able to record behavioral patterns of adults as well as of juveniles.

With respect to adults, extensive activity was observed among females and males, both performing pushups. During observation we followed, on a rock at two meters above the ground, a female repelled three other females which were attempting to reach her. In one instance, there was physical contact between two females, the first jumping on the invading female which then escaped and was purshued a short distance. The "territorial" female then chased for short distances the other two females which appeared to be trying to reach a rock on which an adult male was perched, and in front of which she had been performing several pushups. The male twisted over the rock and intermutlantly licked it. At one point, the female chansed the male. He withdrew a little but later again approached the female which arched her back, and with stiff legs and tail, departed. We did not observe copulation. Pursuits and escapes were observed in various groups of females, these being much more numerous than the males (approximately 10 to 2). In some species females may exhibit territorial defense behavior (Carpen- 
ter, 1978), females may establish home ranges for feeding purposes (Stamps, 1977) but relatively little is known about possible female-female interactions (Crews and Greenberg, 1981). Apparently, the social structure in this species in complex, there is a dominant male and several females. Harems of females associated with one male, are recorded for Iguanids (Carpenter, 1967) and in females of some species of Tropidurus, Carpenter (1977) described agressive behaviors and assertion display as we observed in Tropidurus melanopleurus. However, the brilliant coloration of the female of this species and the comparatively cryptic aspect of the male, are the first indication of an alteration in what is traditionally known in lizards. Here, the female presents and active territorial hebavior which includes the usual Display Action Patterns (Carpenter, 1978) as well as pursuing and biting of other individuals, also with respect to the male, females keep their "female rejection-behavior" described in Carpenter (1983).

As for the juveniles, at 10 meters above ground, on top a rock with a lateral fissure, we observed a group of 25 juveniles over an area of about one square meter. Some of these individuals entered and others came out of the crack. At one point there was pursuing and escape between two juveniles. It is possible that this high density of young in a small area indicated the existence of communal nests, as has been found in other tropidurines (Vitt and Goldberg, 1983).

South America contains an incredible radiation of lizards in the genus Tropidurus. Many of the species have yet to be described and even though there are many recognidez and named species, the phylogenetic relationships among those species remain unknown. Likewise, there is very little information available on the ecology and behavior of this complex assemblage of species. Whith these observations, we hope to call the attention to some peculiarities of the behavior of this species, which suggest the need for a much more detailed study.

\section{ACKNOWLEDGEMENTS}

We are grateful to Dr. R. Etheridge for his valuable suggestions and M. Halloy for the translation.

\section{LITERATURE CITED}

CARPENTER, C.C. 1967. Agg ression and social structure of iguanid lizards. I. W.W. Milstead (ed.) Lizard Ecology : A Sy mposium. pp. 87-105. Univ. Misso uri Press, Columbia.

- 1977. The aggressive displays of three species of South American iguanids lizards of the genus Tropidurus. Herpetologica 33: 385-389.

- 1978. Ritualistic social behaviors in lizards. In Greenberg, N., and MacLean, P.D. (Eds.). Behavior and Neurology of Lizards. Rockville, Md.: National Institutes of Mental Health.

-_. 1983. Communication signals in lizards. Am. Biol. Teach. 45 (6): 306-342.

CREWS, D. and N. GREENBERG. 1981. Function and Causation of Social Signals in Lizards. Amer. Zool. $21: 273-294$.

LAURENT, R.F. 1980. Variación y dimorfismo sexual en el complejo Tropidurus melanopleuruspictus (Iguanidae). Actas VIII Congr. Lat. Zool. Tomo I: $621-626$.

MULLER, L. 1924. Wbernele oder seltene Mittel und sudamerikanische Amphibien und Reptilien. Mitt. Zool. Mus. Berlin. 11:75-93.

PETERS, J.A. and DONOSO BARROS. 1970. Catalogue of the Neotropical squamata. Part II. Lizards and Amphisbaenians. U.S. Nat. Mus. Bull. 297: I-VIII, 1-293.

STAMPS, J.A. 1977. Spacing patterns in lizards. In C. Gans and D.W. Tinkle (eds.). Biology of the Reptilia. Vo1. 7, pp. 265-334. Academic Press, New York.

VITT, L. and S.R. GOLDBERG, 1983. Reproductive Ecology of two tropical iguanids lizards: Tropidurus torquatus and Platynotus semitaen iatus. Cppeia 1983:131-141. 